\title{
The Cracks in the Walls: Earthquakes, Patriarchy, and Transnational Capital in Haitian Free Trade Zones
}

\author{
Joshua E. Olsberg
}

\section{And the Ground Begin to Shake}

The January 10th, 2010 earthquake decimated the Haitian capital of Port-Au-Prince as well as large swaths of the countryside. What was striking was that among the first sectors of the country to resume normal activities, even as vital services remained offline and casualties reached horrific levels, were the Free Trade Zones (FTZs), also called Industrial Parks or Export Processing Zones, outside of Port-Au-Prince as well as along the Haitian-Dominican border. My preliminary inquiries — which involved examining accounts of the situation in post-earthquake Haiti in American newspapers_revealed that a great deal of the coverage was focused on rebuilding economically, with a particular emphasis on the importance of apparel factories in FTZs in this process. This cursory reading prompted me to ask two simple questions, what is the significance of FTZs in Haiti and what is the role of the representations of political economy in shaping our perceptions of these spaces?

Answering these questions however, is not so simple-being trained as a Sociologist, my disciplinary instincts pushed me towards a Marxist analysis of FTZs. I looked at them as spaces of exploitation established by the forces of global capital. It is Marx (2003:245) who says, "Constant capital, the means of production, considered from the standpoint of the creation of surplus-value, only exists to absorb labor, and with every drop of labor a proportional quantity of surplus-labor.... The prolongation of the working-day beyond the natural day... quenches only in a slight degree the vampire thirst for the living blood of labor." To be sure there is a temptation to theorize FTZs as the byproduct of Capital's need, née Capital's thirst, for a cheap and easily exploitable source of labor. This would point to the problem of quenching Capital's thirst and posit something like the following: Given that free trade agreements allow for goods to be produced in Haiti with minimal overhead, particularly because of the abysmal working conditions, low wages, and a near complete lack of substantive protections for labor, it was in the interests of Capital (especially because corporations have no allegiance to the people of the Haiti, only to their shareholders) to ignore all other problems associated with the damage caused by the earthquake and focus on rebuilding the socalled 'productive' center of the economy.

While this argument is not without merit, I began to believe as I continued to trace the transnational connections through an analysis of various texts ranging from media coverage to documents produced by States and entities such as the World Bank and IMF, that it was incomplete. Most problematic is that not only does it fail to explain the gendered division of labor in factories inside FTZs, is it not particularly sensitive to the specificities of history and politics within Haiti. Without revision, it would be guilty of the 'economic reductionist' argument, as outlined by Mouffe (1981), which suggests that this variant Marxism always refer back to the economic (as the only vital principle of social organization) in the last instance. Feminists, among others, have called for attention to be paid to other modes of social organization such as gender. Lisa Brush (2003:46) argues that, "Gender is a principle of social organization," that structures everything from domestic practices within the home to complex institutions 
and state policies. In regards to Haiti, Carolle Charles (1995b) calls for emphasizing, "the centrality of gender oppression in the social fabric of Haitian society," which she suggests is crucial in producing a feminist resistance to the impingement of Capital in Haitian life, and the misery that it has produced. Given such calls, I believe that an analysis that seeks to understand the complexities and significance of FTZs and the way in which they are represented needs to be multifaceted.

First, we should pay close attention to issues of transnational political economy, in particular ongoing development projects (as well as those in the more recent past) under the direction of the World Bank and International Monetary Fund (IMF), both organizations that have intervened at critical junctures to shape Haitian politics. Also, we should closely examine the policies of major Western powers such as the U.S. and France, asking how they have influenced development in Haiti, and explore the ownership and political origins of Free Trade Zones.

Second, we need to closely examine the history of gender, governance, and democracy in Haiti as they shape the nature of citizenship and subjectivity. The production of gendered subjects (along with other vital axes of identity) has important material repercussions for the labor that people do both in the home and in the workplace, thereby impacting the very ways in which we relate to one another in our daily lives.

Keeping these issues in mind allows us to link the specific history and politics of economic governance in Haiti to the way in that it is represented today and ask how those representations either resist or reconstitute the institutionally situated forms of power that allows Capital to pursue its project.

To do this, I draw from a wide variety of textual data and argues that FTZs represent an important social artifact that social scientists can use explore and expand upon theories about the complex relationships between state power, politics, representation, and subjectivity. I do so from a transnational perspective, emphasizing that such complex relationships must be able to wrestle with the often ambiguous and difficult-to-define nature of the borders and boundaries that demarcate nation-states and citizens. Moreover, it argues that an analysis of only the political economy of FTZs - that is, one that only argues for FTZs as a site for Capitalist exploitation-is incomplete as it fails to proclaim the importance of social forms such as gender that shape and shift the biopolitical body upon which such exploitation can take place. I suggest, based upon my reading of Haiti's history and politics, and my analysis of the response to the natural disaster, that the way in which Haiti's "problems" are represented has to be accounted for to understand the reproduction of narrowly defined cultural forms (i.e. gender, the main focus here) as a key component in facilitating the relentless advancement of Capital's project.

\section{A Brief Overview of Contemporary History and Legislation in Haiti: Two 'Docs' and a Priest}

Though this paper will ultimately point to Haiti's colonial past as an integral piece of the analysis offered, at this point it is useful to outline the more recent past in which significant political events, pieces of legislation, and economic policies have shaped Haiti's current juridicio-institutional framework. The point of departure here is the 1986 fall of the Duvalier regime, in which Jean-Claude "Baby Doc" Duvalier was disposed of his place as the head of Haiti's government. The uprising against Duvalier ended the nearly three-decade long grip of the Duvalier's that began in 1957 with Jean-Claude's father Francois "Papa Doc" Duvalier. The end of the Duvalier Era was marked by a renewed voice for Haitian women in the political sphere. As Gina Ulysse (2006:29) suggests, "Without question, women's collective grassroots action was instrumental in the eventually ousting of Jean-Claude Duvalier in 1986. They were at the forefront of social movements and their organic political activities caused changes that led to the first democratic election held in Haiti in 1990." That grassroots collective action of women propelled Jean-Bertrand Aristide into office in December of 1990 is significant and will be discussed further later in this essay. Yet, the political resurgence of women and women's issues was short-lived. Less than seven months later, Aristide himself was ousted by a coup. Carolle Charles' (1995a) details the manner in which this coup sought to obliterate not only the institutional mechanisms by which Aristide ruled, but the political will of his base, largely comprised of women, through the most nefarious of means including, but not limited to, the rape and murder of any of those in opposition to the conspirators.

Perhaps just as disheartening was the fact that the next two decades, which saw Aristide returned and ousted again and his successor Rene Preval elected, would be a period in which the instability created by the coups would 
generate a vacuum in which interventions by foreign governments, the United Nations, the World Bank, the IMF and other transnational entities would remake Haiti in profoundly negative ways. Mark Weisbrot (1997) points out that structural adjustment policies directed by some of these institutions were in place Haiti in the early 1980's, and that Aristide's ascent interrupted the processes engendered by such adjustments. Essentially, Aristide's ouster (in 1990) represents a critical historical switchpoint in the path of Haiti's economic and democratic development. As Winters (2008:288) points out, a large part of Aristide's initial political platform rested upon the promise of instituting a minimum wage and a series of other important labor reforms. Yet such reforms would have been an imposition to the interests of those seeking to exploit Haiti as a cheap source of industrial labor. Even before being deposed, Aristide's leadership was being undermined by powerful foreign-backed interest groups attempting to undermine said policies. The coup was met with immediate disapproval from the U.N., which responded by leveling a trade embargo against Haiti's new military dictatorship. The U.S., at least officially, endorsed the embargo, yet just as quickly backed off from that position. Chomsky (2002:156) argues that the though the embargo was meant to punish the Cedras-led junta, "The Bush administration made it clear, instantly, that it was not going to pay any attention to the sanctions.... Bush established what they called an 'exemption' to the embargo-in other words, about eight-hundred U.S.-owned firms were made 'exempt' from it." This exemption, couched in the rhetoric of not wishing to punish Haitian people for the sins of the Cedras-led junta, was in fact business as usual. Even after Aristide was allowed to return to serve out the last months of his rightfully elected term, it was an essentially pointless exercise, as his political base was decimated by violence.

In the years that would follow, the wheels of neoliberal interventionism would turn. A considerably weakened Aristide, even as he represented a modicum of resistance, would support some neoliberal intrusion. It was in fact Aristide who agreed to break ground on the first textile factory in the newly minted FTZ called Codevi at Ouaniminthe, a region along the Haitian-Dominican border. The Codevi FTZ was a result of a deal stuck between Haiti, the Dominican Republic, and U.S. based, Washington-backed investors. I will elaborate more on Groupo M, the investment group responsible for Codevi later in this paper, but sufficed to say, this type of dealmaking, which pits a vulnerable, debt-burdened and politically destabilized nation against the muscle of Washington and large transnational organizations, is not unusual. As Jane Reagan[1] argues, the plan violated even the sacred principle of private property, by dispossessing framers in Northeastern Haiti of their rightful ownership of the land, in the name of free trade. This dispossession is critical to our ultimate analysis of FTZs and I will discuss it further shortly.

Yasmine Shamsie (2009:652) suggests, "Even the poorest countries with the most profound development challenges are not spared the imperatives of transnational and global markets. In short, their development trajectory must conform to the exigencies neoliberal globalization." In particular, those exigencies produced policies that a weakened Haitian democracy, reeling in the wake of a populist democratic resurgence now in ruins, was unable to resist. Shamsie goes on to outline the emergence of two of such policies, the 2004 Interim Cooperation Framework and the 2007 Poverty Reduction Strategy Paper. Both policies were founded upon the assumption that comes straight from the playbook of the World Bank and IMF-that poverty reduction is a natural consequent of the reduction of barriers and full participation on the part of the developing nation in global trade. Shamsie (2009:650651) rightly implores us to "[consider] the context within which Haiti must craft its economic development strategy today: extreme dependence on outside aid and neoliberalism's continued dominance of the established development orthodoxy." That orthodoxy, which is embedded within a web of social relations beyond the economic realm, saturates each of the aforementioned policies.

From the American side, the emphasis was on Foreign Direct Investment in the neoliberalized Haiti, which produced a series of legislation designed to relax or eliminate regulations. This came in the form of the Haitian Hemispheric Opportunity through Partnership Encouragement Act of 2006 or HOPE. HOPE essentially eliminated tariffs on any importing of apparel made in Haitian textile factories, so long as the fabrics were of U.S. or Haitian origin. The idea was to take advantage of low labor costs so that Haiti could be the assembly site. Predictably, it turned out to be more of a boon for American companies wishing to move manufacturing operations to Haiti than for Haitian people or even the Haitian economy, even after HOPE II, a revised version of the legislation was passed in 2008 .

It is on the heels of all of these changes, the years of destabilization from forces endogamous and exogenous, the multitude of policies and laws, of political disenfranchisement that Haiti found itself in such a terrible state. Then there was an earthquake. 


\title{
Ready to Run
}

Hartwig (2010:i) concludes, "The adoption of a neoliberal rationale to the disaster in Haiti causes practices which support the notion of political control and economic exploitation, and reproduce global structures of inequality." It stands to reason that the bourgeois point-of-view would overemphasize the need to restart, in particular, the export economy, so central to World Bank and IMF development strategies, as soon as possible. Indeed a look at the rhetoric from U.S. news media would support that thesis. A New York Times (from hereon NYT) article[2] from January 22 points out, "The earthquake effectively shut down most textile companies, many of which are in the capital to be close to the port." The article concludes by quoting Haiti's representative to the IMF (who is interestingly Brazilian, not Haitian), who stresses the need to create jobs opportunities for the population. Another NYT article[3], written just a few days later, describes the scene in a textile factory that makes men's apparel for retailers such as Men's Warehouse and Joseph A. Banks. A factory worker points out, "The walls were still standing, but they are cracked.... It is not safe here." Another woman claims, "I'm sitting [at her work station] in a running position."

The article on the one hand emphasizes to just how poor the working conditions and pay are, but counters, "By Haitian standards, where nearly 70 percent of the workers makes less than $\$ 2$ a day, it is a modest improvement." This it argues, "in a country where hopes for economic development have long been frustrated."

An Op-Ed from a few days later[4] articulates it thusly:

\begin{abstract}
Haitians need something more fundamental than relief from the present situation; they need jobs that they can count on for years ahead. For this, the private business sector is essential. Luckily, business leaders are meeting now in Davos, Switzerland, and Haiti is prominent on their agenda.... Haiti is by far the poorest countries in the Western Hemisphere, and yet it need not be so, because unexploited opportunities abound there....if private capital would invest, patiently, in Haitian business. (my emphasis)
\end{abstract}

The real problem for Haiti, as these authors see it, is the lack of transnational Capital having exploited business opportunities there, though they point to Hope II as a step in the right direction, because they argue that it has allowed many garment factories to "become competitive with Chinese garment makers," due to the relaxed restrictions.

Still all of this would seem to fall within the purview of the classical Marxist reading of the situation, that Haiti represents a place in which bourgeois interests have been served by more or less brute force through a long history of colonial repression and now neoliberal repression. While that is true, such an analysis does not quite acknowledge the complexity of how dominance was and continues to be exercised. For one, it ignores a vital aspect of that repression—gender.

Woven into Haiti's long history of colonial control, with its clear emphasis on Capitalist accumulation and exploitation of labor, is an insidious history of the repression of Haitian women. The enforcement of the normative gendered order in Haiti has formed much of the foundation upon which colonial control, even after Haitian independence, has been exercised.

\section{| Patriarchy: From Field to Factory}

Let us step back into history for just a moment. Carolle Charles (1995a) suggests that gender, in many ways, determined the circumstances under which the Haitian struggle for independence took place. She states (1995a:138), "Women [in Southern Haiti prior to the revolution of 1791] began to protest, demanding equal pay, for equal work." Charles argues that from before the revolutionary period onward, Haitian women have been a driving force, because of their instance on challenging gender-based discrimination, in Haitian liberty. The relationship between the two is perhaps most clear in the era of the Duvalier regime. "The Duvaliest state could manipulate gender categories and ideologies for its own political purposes," claims Charles (1995a:141), a statement that seems all the more reasonable given the nature of the resistance that ultimately ended that regime and led to Aristide's election. If it was women's unified voices that led to a freer Haiti, then of course the silencing of those voices was a top priority in regaining control in the name of colonial and ultimately corporate interests. The Cedras junta epitomized that silencing, using various forms of violence against women including abduction, rape, murder, to instill fear in the Aristide electorate. Charles's analysis, particularly because it argues for gender as an organizing principle in both domination and resistance in Haiti, and also because it points to the transnational nature of those gendered relations, 
positing that domination and resistance has occurred as a result of the interaction of forces both endogamous and exogenous to Haiti, troubles Marxist analysis in certain ways. Firstly, it asks how, given that Haiti was the first among Caribbean nations to break away from colonial control, do we see colonial power structures reassert themselves in the relationship established via development projects - the very projects that produced FTZs? Second, it prompts us to ask what is the importance of gender and gender ideology in Haiti's more recent history, from the 1986 ouster of Duvalier until today? Charles' work leads us to see the ideological terrain as one in Haiti in a constant state of struggle. Given this, how might it change the way we should assess U.S.-based media coverage of the earthquake?

It is clear reading the articles from the NYT that there does seem to be a clear articulation of a given ideological frame of reference. Two themes emerged from a reading of NYT articles in the weeks and months after the earthquake the first (detailed earlier in this paper) focused on the need for business to restart promptly and expand quickly, and the second argued for the degree to which Haiti was in a state of chaos, before and after the quake, and argued for a lack of Haitian leadership, before and after the quake.

Again, the first theme might fall squarely into a reductionist Marxist analysis, but the second takes us in another direction. Why, at a time when Haiti was most vulnerable, would there be a need to emphasize chaos and lack of leadership as endemic to Haiti and not a product of Haiti's position within a web transnational connectivities from the U.S. and France, to the World Bank and IMF, and so on? The ahistorical characterization that Haiti's problems are entirely created from within and simply exacerbated by the earthquake is instead about reestablishing the West as a source of patriarchal authority.

\section{| Gendering Haiti}

"Haiti has long been known for its political tumult, for its coups d'etat, years of authoritarian dictatorship and looting of the national treasury for personal gain," suggests an article[5] from January 16, 2010. It continues, "Before the disaster, the country's politicians were known for their distance from the people. Leaders wore expensive suits, flying first class to Miami and driving around in luxury S.U.V.'s. There was a stiff formality among them, in their use of French, their bearing, their sheltered lives in the hills overlooking the slums."

This sort of framing was typical to many of the stories produced after the quake. I would argue that painting Haitian leadership as heartless despots, without acknowledging the history of French and U.S. influence on selecting those leaders, is a reconstruction of a colonial rhetoric positioning White Westerners as the potential saviors of an oppressed people. Another article[6] refers to having to "manage the chaos," the coordinating of which falls to the U.N. Another article[7] argues for the impotence of Haiti's leadership by describing the following scene:

The journalists had assembled and the cameras were rolling. Seated at center stage were the American ambassador and the American general in charge of the United States troops deployed here. At the back of the room, wearing blue jeans and a somber expression, stood President Rene Preval, half-listening to the updates on efforts to help Haiti recover from its devastating earthquake while scanning his cellphone for messages. Then he wandered away without a word.

The emasculation of Preval, and positioning of the ambassador and general at the center of the recovery project reveal gender as a constitutive element of reasserting capitalist Western hegemony in Haiti. The emphasis upon a lack of appropriate leadership and the void it creates justifies Western (male) ambassadors and generals taking charge of the rebuilding and legitimates the reopening of free trades zones even as other services remain obliterated. That FTZs appropriate primarily female labor points to the need for Capital to reimpose its rule by structuring the regime of gendered relations, among other things.

I do not want this point to be misread as class rule appropriating gender and race (thereby giving class the position of primacy among those). In actuality, I want to argue for a rereading of Marx which foregrounds the role of the ideological superstructure in producing the conditions that make the economic base a material possibility. Whereas the tendency in certain strains of Marxist thought has been to focus on the economic base in the last instance as structuring ideology and consciousness, I think it might be more productive to focus on the first instance, that is the instance in which gender and racial ideologies (among others) justify the necessary (re)structuring of institutions to make them amenable to Capital's needs. Such a move, I think, allows us to overcome the problem of the extent to which Capital is or is not bound by the State. Focusing on the first instance allows us to think transnationally and prompts us to ask how gender and racial projects around the world are facilitating or resisting the 
thrust of global Capital. Thinking transnationally means tracing the connectivities that link the expansion of Capital to the imposition of a particular iteration of gendered relations that makes way for the economic conditions in which exploitation take place, and which define the contours of FTZs. Finally, thinking transnationally means attending to the way in which particular discourses that structure the nature of the economic subject-citizen are circulated on the various fields of representation.

\title{
| Resistance in Commercial
}

The title of the film clip[8] is: "Changing Lives at Codevi." A child peers out across a field and in the direction of a white building. He turns with a wide smile. He stands in the factory with a man and woman-his parents? He rides his bike around the factory grounds. The music is soft and rhythmic. Pan across the production floor to women sewing, then back to the child on his bike. The words of the song are translated in neat white letters at the bottom of the screen:

\begin{abstract}
"If you do not see my tears, it is because I am weeping inside. My soul is filled with hope. And although there is suffering, your cries move my heart. The storm is now behind us. And it gives me joy and strength to see the children on their way back to school. Mothers, mothers rejoice. You and I hand in hand, working for a brighter future. With love and passion. With love and passion. I will not fail in our endeavor. To make change in Haiti, we need to work. To rebuild. To make change in Haiti, I will continue to strive to serve my country. With passion and love.
\end{abstract}

The child speaks: "The storm is now behind us. We are working towards a change. In memory of all the fallen. And with love and God as our guide." The sound of applause and the final words, still in white but larger and centered, say to the viewer: "Travay se liberte." (work is freedom)

The caption below the clip (found on YouTube) reads thusly: "This video was developed by and created by the workers of Codevi. Grupo M, of the Dominican Republic, has launched the amazing Codevi Apparel Initiative in Haiti, now employing over 6,000 Haitians, 99.99\% who have never has a job before. Social and environmental accountability are paramount at this inspiring and life changing project." Now juxtapose this imagery to a documentary clip[9] produced by the International Trade Union Confederation (ITUC), which details the experiences of workers in Codevi's factories. The clip follows the story of a worker named Georges, whose efforts to start a labor union with his coworkers was met with both silence and violence from Grupo M's management. Georges talks about the Dominican military attacking labor organizers with little or no pretense. There are no smiling children.

That Grupo M's propaganda stands in stark contrast to the ITUC clip is unsurprising, but it is worth noting several things about the clip. The Grupo M clip valorizes social and environmental responsibility, and in terms of its imagery, reproduces a hetero-patriarchal representation of family on the factory floor-the marriage of labor and sexual (re)production, no pun intended. Its emphasis on community simultaneously belies the intent and motive of Grupo M, which is to maximize profit at whatever expense to labor, while laying bare its gendered and sexualized ideological foundations.

Grupo M moved into Ounaminthe officially in 2003, having brokered a deal with the World Bank (it was in fact the International Finance Corporation, the World Bank's private lending section) to fund the construction of Codevi[10] shortly after the severely enfeebled Aristide agreed to sign into law a bill authorizing free trade zone creation and according to a report[11] produced by the International Confederation of Free Trade Unions (IFCTU), the loan extended by the World Bank, "was conditional on the company's respect for freedom of association and the right to collective bargaining." In terms of management since that time, Grupo M's track record is at best notorious and at worst despicable. Any attempts on labor's part to have been roundly rejected as the ITUC clip attests. That Grupo M plays the authoritarian patriarch is testament to its role as a proxy for Western Capital. The apparel manufacturer has a prestigious lineup of name brands, among those Levi's, Hanes, and Nautica. Consciousness about these companies for many Westerners remains lodged almost exclusively in the circuit of consumption with production processes veiled by the intermediary apparel manufacturer Grupo M. While Grupo M, does the legwork of making (or remaking, as the case may be) ready a space for exploitation, all the while generously funded by transnational flows of capital under Western control, the brand names produced and distributed are available to the Western consumer only as a mélange of symbols provided to them by the culture industry. I believe this partition becomes evident in the mass-mediated identities of the name brands, the articulation of which obfuscates their 
action as political agents. Lo (2002:213) reminds us (by way of his reflections upon the Frankfurt school) that, "media images enthrall and isolate individuals in the mass audience, producing conforming opinions and making open discussion about the state, for example, all but impossible." The problem is evident when, according to Hardt and Negri (2000) we understand that the state (it being comprised of a coalition of powerful actors, not the least of which is the most profound institution of our time-the Corporation), becomes a "sign disconnected from a referent." (Lo 2002:214) I argue, that this disconnect occurs primarily at the site of production, which I believe is an argument consistent with Marxist epistemology.

A readily apparent example of this revolves around Codevi, Grupo M, and it's most popular brand-Levi's Jeans. In June 2011, an article[12] in The Nation detailed the leak of State Department cables (leaked by Wikileaks). The cables showed just how active Levi-Strauss (the company denies this) was in suppressing proposed minimum wage hikes for factory workers, from around $\$ 3$ to $\$ 5$ dollars per day, as far back as 2008 and through 2009. Yet even with the break of the cables by Wikileaks and the follow up story in The Nation, mainstream media emphasized a different news story about Levi's during that timeframe. A few months later in September 2011, Glenn Beck took the opportunity on his television program to denounce Levi's, but the denunciation (Beck said that he is a fan of Levi's jeans but would no longer wear them) was due to an advertisement by the company, which featured a loosely connected group of images, several of which were young people in Levi's jeans standing in defiance of a line of riot police. The ad, Beck claimed[13] was inciting revolution and lauding progressive idealism, saying the following[14]:

It's hard to believe a company associated with American working-class values, would use global revolutions and progressivism to sell their products, but that's exactly what Levi's is doing in their new commercials. Unfortunately, they aren't even trying to disguise their new efforts to commit to the progressive cause.

Beck's response, in its profound superficiality, in fact reveals wealth of information to us relevant to the line of inquiry for this paper. His analysis is limited to the content of the ad-he and his co-hosts watch and Beck suggests that one particular scene "looks like European socialists, marching...looks again, like some sort of Palestinian kind of march. I mean it's gotta be from overseas cause you can see the guy, you know...in the man-burka or whatever that is." Nowhere in his critique of Levi's Company is the slightest bit of attention paid to the production process by which the products come to be, with the exception of one of his cohosts reading an announcement on Levi's website stating that they intend to comply with the U.N. Millenium Development goals to improve the lives of workers at production sites. Rather than call Levi's out on their hypocrisy, particularly given their lobbying efforts revealed by Wikileaks, Beck and his cadre chuckle at the mention of Levi's promise to comply with the U.N., a villain in the new philosophy of the far right. Beck raises his voice and asks, "What has happened to us? We're sitting passively by, and our neighbors say 'don't worry about it.' Don’t worry about it!”

That Beck's disagreement is lodged completely in the ideological realm conjured by the texts embedded in the ad, that 'American working-class values' are threatened not by the oppression of workers' rights in Haitian factories, but by the dramatization of vaguely displayed resistance is telling. What I believe it tells us is what is confirmed by the Frankfurt school, Hardt and Negri, and others when it comes to the problem of resistance to the State, but I will add something; I believe it tells us much about the FTZ as a constructed social space, and how both the missions and machinations of Transnational Capital and the exigencies of the history of gender, governance, and democracy in Haiti come together.

\section{Sovereignty and Biopower in Haiti}

Giorgio Agamben (1998:03) forwards the notion of a 'threshold of biological modernity' that he claims, "Is situated at the point in which the species and the individual as a simply living body become what is at stake in society's political strategies." It would certainly seem that the rise of neoliberalism is the harbinger of having reached that threshold. Wendy Brown (2003) points out that neoliberalism is something more than just an extreme variant of economic liberalism, arguing, "The neoliberal formulation of the state and especially of the specific legal arrangements and decisions as the precondition and ongoing condition of the market does not mean the market is controlled by the state but precisely the opposite." Insofar as the state has to be concerned with the specific legal arrangements and decisions as the precondition of instituting and insuring market rule, thereby ensuring Capital is free to pursue is vampiric project, the state then must be concerned with the subjugation of all 
forms of social relations to markets. I believe this way of thinking emphasizes the first instance and can allow us to reconcile some of the more problematic aspects of Marxian analysis by focusing on what Agamben (1998:06) calls the, "hidden point(s) of intersection between the juridicio-institutional and the biopolitical models of power," of which FTZs are a prime example. Melissa Wright (1999:455) details the 'dialectical stillness' of the maquila in which "Mexican women represent workers of declining value since their intrinsic value never appreciates into skill but instead dissipates over time." She continues, "Meanwhile her antithesis— the masculine subject—emerges as the emblem of the other kind of variable capital whose value appreciates over time." The unskilled woman laborer then is the automaton whose gears and gadgets allow for the completion of a menial task for a delimited amount of time, which can then be easily replaced. To listen to the transnational powers that be, this automaton is in one respect Haiti's greatest asset. A report from the Congressional Research Service[15] in June 2010 says this of the possibilities of the Haitian apparel industry:

Haiti is a prime candidate for redeveloping the apparel exporting industry because assembly requires an abundance of lowskill labor, but relies on relatively simple technology and small capital investment. Therefore, production naturally gravitates towards locations with low labor costs. Although Haiti's labor costs are not as low as those in some Asian countries, they are the lowest in the region, allowing Haiti to niche into apparel assembly.

However, the report suggests some constraints on the possibility of Haiti becoming a major player in this industry:

There are some key challenges to Haitian apparel competitiveness. One is producer concerns over losing a major cost advantage because of the large 2009 minimum wage increase. Apparel managers note that even though fully trained workers already earn more than the new minimum wage, raising the minimum wage can reduce the worker production incentives.

Essentially, FTZs are the byproduct of the neoliberal state's (itself a transnational entity) reconfiguring not only economic relations but also gendered relations, both of which converge materially and discursively in the factory space.

Agamben (1998:168-169) argues that the camp (the internment camp) is the 'nomos' of modernity, a space of inclusive-exclusion in which those within are fixed in the 'state of exception.' He goes on:

In the camp, the state of exception, which was essentially a temporary suspension of the rule of law on the basis of a factual state of danger, is now given a permanent spatial arrangement, which as such nevertheless remains outside of the normal order.

A cursory reading sees apparel factories in FTZs as ideal sites for the stripping of surplus value, which is true, yet a reading that foregrounds gender as the category of analysis sees the 'original sin' here as one in which autonomy and political agency of Haitian women was stripped in the violence of the 1991 coups. This act madeready the docile, feminized biopolitical body by producing a site of inclusive-exclusion. The 'factual state of danger' described by Agamben that allows for the establishment of the camp is indeed in the Haitian case the threat to the interests of U.S.-backed World Bank/IMF development projects. J.K. Gibson-Graham (1996:79) argue that in the "discourse of Capitalism, woman is constituted as an economic actor allocated to the subordinate functions of the capitalist system... she is a crucial constituent of capitalist social relations, though not situated at the center of accumulation, nor cast as a subject of history." In this case, Gibson-Graham were examining women's consumptive practices, yet a transnational analysis would also implore the reader to examine the subordinate role of women in capitalist production. Our reading of Haitian history suggests women are a crucial constituent of capitalist social relations, yet the original sin of delimiting and destroying the agency and political autonomy of Haitian women had to be committed in order for the state of exception to be a possibility, and indeed crystallize in the form of the FTZ and its factory-camp. That men also work and are exploited in these factories does not mean that they are not gendered, by virtue of being stripped politically and subject to a patriarchal structure from without, as feminine and thereby subjugated by the regime of gender produced by the intercourse of local history and politics and Capital's conquest.

\section{Don't Fence Me In!}

Polyani (1944) teaches us that the conquest of Capital in England began with the enclosure of common lands 
so that they could be used for sheep pastures in order to jumpstart the textile industry. The result was a social catastrophe as displaced masses, once able to at least scratch out an existence through small-scale agricultural practice on those common lands, moved into the cities as an unskilled workforce. The misery Marx encountered at the outset of the industrial age was the reverberation of this displacement. Yet it was not the fences themselves that represent the first instance, the original sin was the decision by the profoundly wealthy and influential of day to redefine nothing less than the character of the biopolitical body. That biopolitics became possible only with the advent of Capitalism, as well as the necessary technological advancements (to say nothing of the role of social sciences), is because Capital required the kind of subject amenable to fulfilling its desires and ultimately had to be compelled to act upon whatever social forms stood in its way. It could not do in a vacuum, rather it has always built upon what is in place, and rebuilds upon that again. Agamben's contribution to Marxist epistemology is to use the camp to understand the intersection of the biopower and sovereign power, to focus again on powerful actors' taking up of historically specific iterations of gender, etc. to their own ends-this paper demonstrates just that.

That Ounaminthe required a dispossession of the same sort, the removal of small-scale farmers from what would be the FTZ site, is not surprising, but what again has to be emphasized is the first instance. That instance in which Haiti and Haitian people were gendered according to the narrowest definition, a definition that inexorably linked them to markets and which rendered anything that did not fit within that constellation of meanings indecipherable to Western eyes. The subject here, feminized and therefore subjugated (because Capital is masculine) is rendered politically voiceless first, and put to work next. The Catch-22 of the framework of global capitalism is just this: Whereas in the so-called first world, citizenship is the basis for rights and freedoms because it gives one the opportunity to participate in the political process however superficial it may be, in the third-world participation in the labor market is the only connection to citizenship, yet that labor market comes about through the removal of the possibility of freedom. Capital rids itself the yokes of civic participation in the third world-it does this by reinstating a particular gendered and racialized regime by forcibly removing an emancipatory alternative while representing the exclusion as the emancipatory act. In Haiti, the FTZ is what fills the void left by that exclusion. A space of non-citizenship that reminds the non-citizens that "work is freedom" even as the basis of that work is established through a repression that places the throat of the laborer under the boot of the white father. In the German Ideology, Marx (1983) suggests that ideology presents the world in an inverted way, similar to a "camera obscura"- - here we see that in the representation of issues of political economy as it regards to FTZ, gender and race in particular are the mechanisms by which that distorted image is produced, and are integral to Capital's project. The inversion facilitates the ongoing need to consume surplus labor and the need to continually reauthorize that consumptive practice.

To the credit of workers in Haitian FTZs they continue to resist with the weight of violence (physical and epistemic) looming over them, and most importantly, they continue to strive to reclaim the FTZ factory space for themselves. Moreover, those of us outside of the factory-camp's walls must strive to assist by challenging the dominant forms of representation that reauthorize the exploitation.

Haiti has shown a remarkable tendency towards grassroots Democratic action, and often on the backs of strong and politically emancipated women. Though Haitian women have been the most common victims of political violence, it is just as important for us to see the power in their persistent resiliency, which makes the FTZ camp a site that may be reclaimed in a way that reverberate beyond its fenced and cracked walls.

\section{Authors Note}

This paper seems to indicate, at least to me, the need to continue to explore and elaborate upon Althusser's notion of the Ideological State Apparatus, particularly as it regards to forms of media, whether they be new or old. The outpouring of support for Haiti in the U.S. post-earthquake is interesting as whatever attention that was paid seemed to preclude a substantive public discussion on Haitian politics and history, or the role of U.S. interventions in the past and present. It was more of a purely emotional response, which is not necessarily remarkable unless juxtaposed against the lack of critical analysis. However, when we do choose to explore that, we see that Lauren Berlant's (2005) argument that politics has been reduced to a "mass-mediated visceral engagement," in which hegemony is maintained in the form of a pre-established "zone of collective intimacy" not only along the fault lines of issues of political economy, but of gender, race, and so on. 


\section{Endnotes}

1. 'We're Seizing Your Land to Help Free You." The Progress Report. www.progress.org/land36.htm

2. "Economy in Shock Struggles to Restart." Simon Romero. New York Times. 01/22/2010.

3. "A Factory Sputters Back to Life in Haiti." Ray Rivera. New York Times. 01/25/2010.

4. "Building Haiti's Economy, One Mango at a Time." Paul Collier and Jean-Louis Warnholz. New York Times. 01/29/2010.

5. "Government Struggles to Exhume Itself." Simon Romero and Marc Lacey. New York Times. January 16, 2010.

6. "Obstacles to Recovery in Haiti May Prove Daunting Beyond Other Disasters." Ray Rivera. New York Times. January 23, 2010.

7. "In Quake's Wake, Haiti Faces Leadership Void." New York Times. Ginger Thompson and Mark Lacey. February 1, 2010.

8. http://youtu.be/9WHytmg15Lc

\author{
9. http://youtu.be/SgkJS9ehfVY \\ 10. http://www.grupom.com.do/site/
}

11. "Behind the Brand Names:Working Conditions and Labor Rights in Export Processing Zones." Sarah Perman, Laurent Duvillier, Natacha David, John Eden and Samuel Grumiau." International Confederation of Free Trade Unions. December 2004.

12. "Let Them Live on \$3 Per Day." Dan Coughlin and Kim Ives. June 1, 2011.

13. http://www.glennbeck.com/2011/09/20/levisguarantees-denouncement-from-glenn-beck/

14. "Glenn Beck Disses Levi's; Levi's Ok With That." Sarah Duxbury. San Francisco Business Times. September 21, 2011.

15. "The Haitian Economy and the HOPE Act." J.F. Hornbeck. Congressional Research Service. $06 / 24 / 2010$

\section{References}

Agamben, Giorgio. 1998. Homo Sacer: Sovereign Power and Bare Life. Stanford University Press.

Althusser, Louis. 2001. "Ideology and the Ideological State Apparatus." in Lenin and Philosophy and Other Essays. Monthly Review Press.

Berlant, Lauren. 2005. “The Epistemology of State Emotion.” in Dissent in Dangerous Times. Austin Sarat, ed. University of Michigan Press.

Brown, Wendy. 2003. "Neo-liberalism and the End of Liberal Democracy." Theory \& Event 7:1. Johns Hopkins University Press.

Brush, Lisa. 2003. Gender and Governance. Altamera Press.

Charles, Carolle. 1995a. "Feminist Action and Research in Haiti." Caribbean Studies, 28:01, pp. 61-75. Institute of Caribbean Studies.

Charles, Carolle. 1995b. "Gender and Politics in Contemporary Haiti: The Duvalierist State, Transnationalism, and the Emergence of a New Feminism (1980-1990). Feminist Studies, 21:01, pp. 135-164. Feminist Studies Inc.
Chomsky, Noam and Peter Mitchell. 2002. Understanding Power: The Indispensable Chomsky. New Press.

Gibson-Graham, J.K. 1996. The End of Capitalism as We Knew It: A Feminist Critique of Political Economy. Minnesota Press.

Hardt, Michael and Antonio Negri. 2000. Empire. Harvard University Press.

Hartwig, Catalin. 2010. "Letting Silences Speak: Deconstructing the Discourse of Rebuilding in Post-Earthquake Haiti." M.A. Thesis. Dept. of International Relations and European Studies. Central European University.

Lo, Clarence. 2001. "Marxist Models of the Capitalist State and Politics." in Theoretical Directions in Political Sociology for the 21st Century, Research in Political Sociology vol 11. Elsievier Science.

Marx, Karl. 1983. "On the German Ideology" in The Portable Karl Marx. Penguin Publishers. New York.

Marx, Karl. 2003. Capital, Vol. 1. International Publishers. 
Mouffe, Chantal. 1981. "Hegemony and Ideology in Gramsci." In Culture, Ideology, and Social Process: A Reader. ed. Tony Bennett. Open University Press.

Polyani, Karl. 1944. The Great Transformation: The Political and Economic Origins of Our Time. Beacon Press.

Shamsie, Yasmine. 2009. "Export Processing Zones: The Purported Glimmer in Haiti's Development Murk." Review of International Political Economy, 16:4, pp. 649- 672. Taylor \& Francis.

Ulysse, Gina. 2006. "Papa, Patriarchy, and Power: Snapshots of a Good Haitian Girl,

Feminism, \& Dyasporic Dreams." Journal of Haitian Studies, 12:01. pp. 24-45.
Weisbrot, Mark. 1997. "Structural Adjustment in Haiti." Monthly Review: An Independent Socialist Magazine, 48:08.

Winter, Cecilia. 2008. "Institution Building in Haiti: An Assessment of the Interim

Cooperation Building Framework 2004-2006." Journal of Human Development, 9:02. United Nations Development Programme.

Wright, Melissa. 1999. "The Dialectics of Still Life: Murder, Women, and Maquiladoras." Public Culture, 11:3, pp. 453-474. Duke University Press. 
